\title{
Mercury-Free Preparation and Selective Reactions of Propargyl (and -ic) Grignard Reagents
}

Hukum P. Acharya, Kei Miyoshi, and Yuichi Kobayashi*

Department of Biomolecular Engineering, Tokyo Institute of Technology

Box B52, 4259 Nagatsuta-cho, Midori-ku, Yokohama 226-8501

Japan

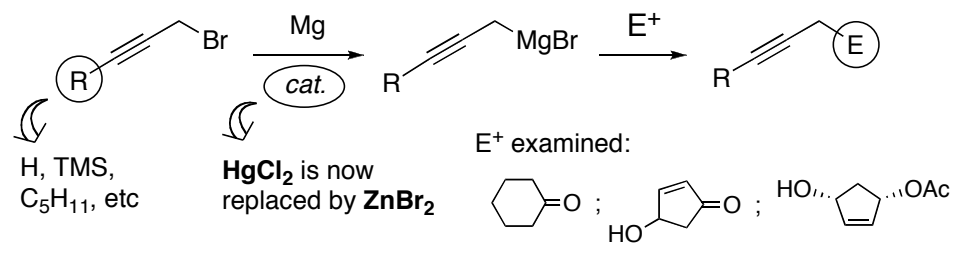

Procedures $\quad$ S1-S9

References $\quad$ S10

Spectra S11-S17 
General. The ${ }^{1} \mathrm{H}$ NMR $(300 \mathrm{MHz})$ and ${ }^{13} \mathrm{C}$ NMR $(75 \mathrm{MHz})$ spectra were measured in $\mathrm{CDCl}_{3}$. Magnesium and $\mathrm{ZnBr}_{2}$ were purchased from Nacalai Tesque, Japan. The following solvents were distilled before use: THF (from Na/benzophenone), $\mathrm{Et}_{2} \mathrm{O}$ (from $\mathrm{Na}$ /benzophenone), and $\mathrm{CH}_{2} \mathrm{Cl}_{2}$ (from $\mathrm{CaH}_{2}$ ). Silica gel from Merck (silica gel 60) was used for chromatography.

Preparation of Propargyl Grignard Reagent 2a. The flask charged with $\mathrm{ZnBr}_{2}(120$ $\mathrm{mg}, 4 \mathrm{~mol} \%, 0.53 \mathrm{mmol})$ and $\mathrm{Mg}(650 \mathrm{mg}, 27 \mathrm{mg}$-atom) was heated under vacuum and flushed with Ar. To this were added $\mathrm{Et}_{2} \mathrm{O}(10 \mathrm{~mL})$ and propargyl bromide (1a) $(1.0 \mathrm{~mL}, 13$ $\mathrm{mmol})$ in $\mathrm{Et}_{2} \mathrm{O}(8 \mathrm{~mL})$ dropwise. Immediately after the addition, exothermic reaction took place and the mixture was cooled to $0{ }^{\circ} \mathrm{C}$ (ice-cold water). Addition of 1 a took $40 \mathrm{~min}$, and the mixture was stirred at the same temperature for further $1 \mathrm{~h}$ to afford a light green supernatant and pulverized $\mathrm{Mg}$ precipitates. The supernatant was $0.52 \mathrm{M}$ by titration using methyl orange as an indicator ( $74 \%$ yield).

Preparation of Propargylic Grignard Reagent 2b. The flask charged with $\mathrm{ZnBr}_{2}(50$ $\mathrm{mg}, 0.22 \mathrm{mmol})$ and $\mathrm{Mg}$ (505 mg, $21 \mathrm{mg}$-atom) were heated under vacuum, flushed with $\mathrm{Ar}$, and added $\mathrm{Et}_{2} \mathrm{O}(6 \mathrm{~mL})$. After the addition of TMS-propargylic bromide (1b) $(2.0 \mathrm{~g}$, $10.4 \mathrm{mmol})$ in $\mathrm{Et}_{2} \mathrm{O}(8 \mathrm{~mL})$ was started, exothermic reaction took place and the mixture was cooled to $0{ }^{\circ} \mathrm{C}$ (ice-cold water). After the addition (over $30 \mathrm{~min}$ ) the mixture was stirred on an ice-water bath for $2 \mathrm{~h}$ to afford a light yellow supernatant and pulverized $\mathrm{Mg}$ precipitates. The concentration of supernatant was $0.56 \mathrm{M}$ by titration using methyl orange as an indicator (86\% yield).

Preparation of Propargylic Grignard Reagents $2 c$ and 2d. The reagents were prepared as described above: $2 \mathbf{c}, 0.56 \mathrm{M}, 85 \%$ yield; $2 \mathbf{d}, 0.47 \mathrm{M}, 83 \%$ yield.

1-(Prop-2-ynyl)cyclohexanol (9a). To an ice-cold solution of $8(47 \mathrm{mg}, 0.48 \mathrm{mmol})$ in THF $(5 \mathrm{~mL})$ was added $2 \mathrm{a}\left(1.2 \mathrm{~mL}, 0.52 \mathrm{M}^{\text {in }} \mathrm{Et}_{2} \mathrm{O}, 0.62 \mathrm{mmol}\right)$ dropwise. The solution was stirred at the same temperature for $30 \mathrm{~min}$ and diluted with saturated $\mathrm{NH}_{4} \mathrm{Cl}$ and hexane. The organic layer was separated, and the aqueous layer was extracted with hexane. The combined organic layers were dried over $\mathrm{MgSO}_{4}$ and concentrated under reduced 
pressure to leave an oil, which was a $94: 6$ mixture of 9a and 10a by ${ }^{1} \mathrm{H}$ NMR spectroscopy. The residual oil was purified by column chromatography (hexane/EtOAc) to afford the mixture (94: 6 by ${ }^{1} \mathrm{H}$ NMR, $64 \mathrm{mg}, 96 \%$ combined yield). The ${ }^{1} \mathrm{H}$ NMR spectrum $(300 \mathrm{MHz})$ of the major product 9a was consistent with that reported. ${ }^{1,2,3}$

1-(3-(Trimethylsilyl)prop-2-ynyl)cyclohexanol (9b). To a solution of 8 (95 mg, 0.97 $\mathrm{mmol})$ in THF $(10 \mathrm{~mL})$ at $-20{ }^{\circ} \mathrm{C}$ was added $\mathbf{2 b}\left(2.9 \mathrm{~mL}, 0.40 \mathrm{M}\right.$ in $\left.\mathrm{Et}_{2} \mathrm{O}, 1.16 \mathrm{mmol}\right)$ dropwise. The solution was stirred at the same temperature for $1 \mathrm{~h}$ and quenched with saturated $\mathrm{NH}_{4} \mathrm{Cl}$ and hexane. The organic layer was separated, and the aqueous layer was extracted with hexane. The combined organic layers were dried over $\mathrm{MgSO}_{4}$ and concentrated under reduced pressure to furnish an oily residue, which was purified by column chromatography (hexane/EtOAc) to afford 9b and 10b (97: 3 by ${ }^{1} \mathrm{H}$ NMR, $202 \mathrm{mg}$, $99 \%$ combined yield). The ${ }^{1} \mathrm{H}$ NMR spectrum $(300 \mathrm{MHz})$ of the major product $9 \mathrm{~b}$ was consistent with that reported. ${ }^{4,5}$

$\left(1 R^{*}, 3 R^{*}\right)$-1-(3-(Trimethylsilyl)prop-2-ynyl)cyclopent-4-ene-1,3-diol (13). To a solution of $11(25 \mathrm{mg}, 0.255 \mathrm{mmol})$ in THF $(2.5 \mathrm{~mL})$ at $-10{ }^{\circ} \mathrm{C}$ was added $\mathbf{2 b}(1.4 \mathrm{~mL}, 0.41$ $\mathrm{M}$ in $\mathrm{Et}_{2} \mathrm{O}, 0.57 \mathrm{mmol}$ ) dropwise. The solution was stirred at the same temperature for $1 \mathrm{~h}$ and diluted with saturated $\mathrm{NH}_{4} \mathrm{Cl}$ and EtOAc. The organic layer was separated, and the aqueous layer was extracted with EtOAc three times. The combined organic extracts were dried over $\mathrm{MgSO}_{4}$ and concentrated under reduced pressure to leave a residue, which was purified by column chromatography (hexane/EtOAc) to afford $\mathbf{1 3}$ and the allenic alcohol (97 : 3 by ${ }^{1} \mathrm{H}$ NMR, $50 \mathrm{mg}$, 93\% combined yield). The ${ }^{1} \mathrm{H}$ NMR spectrum (300 MHz) of the major product $\mathbf{1 3}$ was consistent with that reported. ${ }^{6}$

$\left(1 R^{*}, 4 R^{*}\right)-4-(3-($ Trimethylsilyl)prop-2-ynyl)cyclopent-2-enol (16). To an ice-cold slurry of $\mathrm{MgCl}_{2}(7.0 \mathrm{~mL}, 0.40 \mathrm{M}$ in THF, $2.80 \mathrm{mmol})$ was added $\mathbf{2 b}(3.1 \mathrm{~mL}, 0.45 \mathrm{M}$ in $\mathrm{Et}_{2} \mathrm{O}, 1.40 \mathrm{mmol}$ ), and the mixture was stirred at $0{ }^{\circ} \mathrm{C}$ for $30 \mathrm{~min}$. To this was added was added $\mathrm{CuCN}$ (147 mg, $1.48 \mathrm{mmol}$ ). After $10 \mathrm{~min}$ at $0{ }^{\circ} \mathrm{C}$, monoacetate 14 (50 mg, 0.35 $\mathrm{mmol})$ in THF ( $2 \mathrm{~mL}$ ) was added. The mixture was stirred at the same temperature for $4 \mathrm{~h}$ and poured to saturated $\mathrm{NH}_{4} \mathrm{Cl}$, few drops of $\mathrm{NH}_{3}$ solution, and hexane. The organic layer was separated and the aqueous layer was extracted with hexane twice. The combined organic fractions were dried over $\mathrm{MgSO}_{4}$ and concentrated to obtain a mixture of $\mathbf{1 6}$ and $\mathbf{1 7}$ 
in a $94: 6$ ratio by ${ }^{1} \mathrm{H}$ NMR spectroscopy. The mixture was purified by column chromatography (hexane/EtOAc): $52 \mathrm{mg}, 77 \%$ combined yield. The spectral data of 16: IR (neat) 3338, 2174, 1250, $842 \mathrm{~cm}^{-1} ;{ }^{1} \mathrm{H}$ NMR (300 MHz, $\mathrm{CDCl}_{3}$ ) $\delta 0.13$ (s, $\left.9 \mathrm{H}\right), 1.60$ (br s, 1 H), 1.88-1.98 (m, $2 \mathrm{H}), 2.24-2.28$ (m, $2 \mathrm{H}), 3.02-3.15$ (m, $1 \mathrm{H}), 4.86-4.94(\mathrm{~m}, 1 \mathrm{H}), 5.88$ $(\mathrm{dt}, J=6,2 \mathrm{~Hz}, 1 \mathrm{H}), 5.95(\mathrm{dd}, J=6,2 \mathrm{~Hz}, 1 \mathrm{H}) ;{ }^{13} \mathrm{C} \mathrm{NMR}\left(75 \mathrm{MHz}, \mathrm{CDCl}_{3}\right) \delta 0.13(-)$, $25.9(+), 39.8(+), 43.6(-), 77.1(-), 85.5(+), 105.5(+), 134.0(-), 138.2(-)$.

(1S,4R)-4-Hydroxycyclopent-2-enyl Pivaloate (19). To an ice-cold solution of acetate $(1 R)-14$ (1.50 g, $10.6 \mathrm{mmol},>99 \%$ ee by chiral HPLC), DMAP (130 mg, $1.06 \mathrm{mmol})$, and $\mathrm{Et}_{3} \mathrm{~N}(7.43 \mathrm{~mL}, 52.7 \mathrm{mmol})$ in $\mathrm{CH}_{2} \mathrm{Cl}_{2}(21 \mathrm{~mL})$ was added pivaloyl chloride $(2.60 \mathrm{~mL}, 21.1$ $\mathrm{mmol}$ ) dropwise. The solution was stirred at $\mathrm{rt}$ for $10 \mathrm{~h}$ and the excess chloride was quenched by addition of $\mathrm{Me}_{2} \mathrm{~N}\left(\mathrm{CH}_{2}\right)_{3} \mathrm{NH}_{2}(2.25 \mathrm{~mL}, 32 \mathrm{mmol})$. The mixture was stirred at rt for $30 \mathrm{~min}$ and diluted with saturated $\mathrm{NaHCO}_{3}$. The mixture was extracted with EtOAc three times. The combined extracts were dried over $\mathrm{MgSO}_{4}$ and concentrated. The residue was subjected to chromatography on silica gel to afford the pivaloate ester of $(1 R)-\mathbf{1 4}$, which was used for the next reaction without further purification.

A mixture of the above ester and $\mathrm{K}_{2} \mathrm{CO}_{3}(1.60 \mathrm{~g}, 11.6 \mathrm{mmol})$ in $\mathrm{MeOH}(20 \mathrm{~mL})$ was stirred at $\mathrm{rt}$ for $20 \mathrm{~min}$, diluted with saturated $\mathrm{NH}_{4} \mathrm{Cl}$ and EtOAc with vigorous stirring. The phases were separated and the aqueous phase was extracted with EtOAc three times. The filtrate was concentrated and the residue was purified by chromatography on silica gel to afford mono-pivaloate 19 (1.57 g, 81\% yield): $[\alpha]_{\mathrm{D}}^{26}-68\left(c 0.404, \mathrm{CHCl}_{3}\right)$; IR (neat) 3428 , 1725, $1159 \mathrm{~cm}^{-1}$; ${ }^{1} \mathrm{H}$ NMR (300 MHz, $\mathrm{CDCl}_{3}$ ) $\delta 1.18$ (s, $\left.9 \mathrm{H}\right) 1.60$ (dt, $\left.J=14,4 \mathrm{~Hz}, 1 \mathrm{H}\right)$, $1.77(\mathrm{~d}, J=6 \mathrm{~Hz}, 1 \mathrm{H}), 2.81(\mathrm{dt}, J=14,7 \mathrm{~Hz}, 1 \mathrm{H}), 4.66-4.78(\mathrm{~m}, 1 \mathrm{H}), 5.43-5.51(\mathrm{~m}, 1 \mathrm{H})$, $5.96(\mathrm{ddd}, J=6,2,1 \mathrm{~Hz}, 1 \mathrm{H}), 6.10(\mathrm{ddd}, J=6,2,1 \mathrm{~Hz}, 1 \mathrm{H}) ;{ }^{13} \mathrm{C} \mathrm{NMR}\left(75 \mathrm{MHz}, \mathrm{CDCl}_{3}\right)$

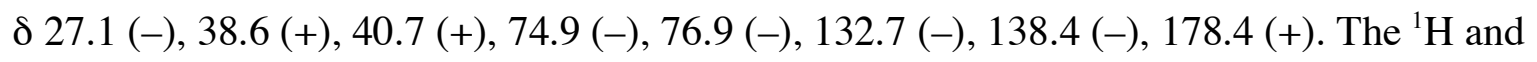
${ }^{13} \mathrm{C}$ NMR spectra were identical with those reported. ${ }^{7}$

$(1 R, 4 R)$-4-(3-(Trimethylsilyl)prop-2-ynyl)cyclopent-2-enol ((1R)-16). A solution of $\mathrm{MgCl}_{2}$ in THF was prepared from $\mathrm{Mg}$ (972 mg, $40.0 \mathrm{mg}$-atom) and 1,2-dichloroethane $(9.50 \mathrm{~mL}, 120 \mathrm{mmol})$ in THF $(100 \mathrm{~mL})$ according to the above procedure. The solution was cooled to $0{ }^{\circ} \mathrm{C}$ and added $2 \mathbf{b}\left(38 \mathrm{~mL}, 0.52 \mathrm{M}^{\text {in }} \mathrm{Et}_{2} \mathrm{O}, 19.8 \mathrm{mmol}\right)$ and, after $15 \mathrm{~min}$, $\mathrm{CuCN}(2.20 \mathrm{~g}, 24.6 \mathrm{mmol})$. The mixture was stirred for $15 \mathrm{~min}$ and added mono-pivaloate 19 (324 mg, $1.76 \mathrm{mmol}$ ) dissolved in THF $(5 \mathrm{~mL})$. The reaction was carried out at $0{ }^{\circ} \mathrm{C}$ 
for $2 \mathrm{~h}$ and quenched by addition of saturated $\mathrm{NH}_{4} \mathrm{Cl}, 28 \% \mathrm{NH}_{3}$, and EtOAc with vigorous stirring. The phases were separated and the aqueous phase was extracted with EtOAc three times. The combined organic phases were dried over $\mathrm{MgSO}_{4}$ and concentrated. The product was a $93: 7$ mixture of $(1 R)-\mathbf{1 6}$ and the regioisomer by ${ }^{1} \mathrm{H}$ NMR spectroscopy, which was separated by chromatography on silica gel to afford (1R)-16 (274 mg, 80\% yield) and the regioisomer (21 mg, 6\% yield). (1R)-16: $[\alpha]^{25}+185\left(c 0.26, \mathrm{CHCl}_{3}\right)$. The ${ }^{1} \mathrm{H}$ and ${ }^{13} \mathrm{C}$ NMR spectra were identical with those obtained for the racemic product (vide supra).

(3R,5R)-3-(tert-Butyldimethylsilyloxy)-5-(prop-2-ynyl)cyclopentene (20). To a solution of alcohol (1R)-16 (204 mg, $1.05 \mathrm{mmol})$ in DMF (5 mL) were added imidazole (286 mg, $4.20 \mathrm{mmol})$ and TBSCl (316 mg, $2.10 \mathrm{mmol})$. The solution was stirred at $\mathrm{rt}$ for 1 $\mathrm{h}$ and diluted with saturated $\mathrm{NaHCO}_{3}$ and hexane with vigorous stirring. The layers were separated, and the aqueous layer was extracted with hexane three times. The combined organic layers were dried over $\mathrm{MgSO}_{4}$ and concentrated to obtain the silyl ester of $(1 R)-\mathbf{1 6}$, which was used for the next reaction without further purification: characteristic signals of ${ }^{1} \mathrm{H}$ NMR (300 MHz, $\mathrm{CDCl}_{3}$ ) $\delta 1.82-1.99$ (m, $2 \mathrm{H}$ ), 2.24 (d, $\left.J=7 \mathrm{~Hz}, 2 \mathrm{H}\right), 3.00-3.12$ (m, 1 H), 4.91-5.01 (m, $1 \mathrm{H}), 5.76(\mathrm{dt}, J=5,2 \mathrm{~Hz}, 1 \mathrm{H}), 5.86(\mathrm{dm}, J=5 \mathrm{~Hz}, 1 \mathrm{H})$.

A mixture of the above ester and $\mathrm{K}_{2} \mathrm{CO}_{3}(435 \mathrm{mg}, 3.15 \mathrm{mmol})$ in $\mathrm{MeOH}(5 \mathrm{~mL})$ was stirred at $\mathrm{rt}$ for $1 \mathrm{~h}$ and diluted with saturated $\mathrm{NH}_{4} \mathrm{Cl}$ and $\mathrm{Et}_{2} \mathrm{O}$ with vigorous stirring. The phases were separated, and the aqueous phase was extracted with $\mathrm{Et}_{2} \mathrm{O}$ three times. The combined organic layers were dried over $\mathrm{MgSO}_{4}$ and concentrated to afford an oil, which was purified by chromatography on silica gel (hexane/EtOAc) to afford acetylene 20 (209 mg, 88\% yield from $(1 R)-16)$ : $[\alpha]^{27}+142\left(c 0.166, \mathrm{CHCl}_{3}\right)$; IR (neat) 3313, 1252, 1070, $837 \mathrm{~cm}^{-1} ;{ }^{1} \mathrm{H}$ NMR $\left(300 \mathrm{MHz}, \mathrm{CDCl}_{3}\right) \delta 0.08(\mathrm{~s}, 6 \mathrm{H}), 0.89(\mathrm{~s}, 9 \mathrm{H}), 1.89-1.95(\mathrm{~m}, 3 \mathrm{H})$, $2.22(\mathrm{dd}, J=7,3 \mathrm{~Hz}, 2 \mathrm{H}), 3.04-3.16(\mathrm{~m}, 1 \mathrm{H}), 4.86-5.00(\mathrm{~m}, 1 \mathrm{H}), 5.79(\mathrm{dt}, J=5,1 \mathrm{~Hz}, 1$ $\mathrm{H}), 5.84-5.92(\mathrm{~m}, 1 \mathrm{H}) ;{ }^{13} \mathrm{C} \mathrm{NMR}\left(75 \mathrm{MHz}, \mathrm{CDCl}_{3}\right) \delta-4.5(-), 18.4(+), 24.7(+), 26.0(-)$, $40.0(+), 43.5(-), 68.9(+), 77.5(-), 83.0(+), 134.7(-), 136.7(-)$.

(3R,5R)-3-(tert-Butyldimethylsilyloxy)-5-(oct-2-ynyl)cyclopentene (21). To a solution of acetylene $20(183 \mathrm{mg}, 0.774 \mathrm{mmol})$ in THF $(6.4 \mathrm{~mL})$ at $-78^{\circ} \mathrm{C}$ was added $n$-BuLi ( $0.61 \mathrm{~mL}, 1.63 \mathrm{M}$ in hexane, $0.994 \mathrm{mmol})$ dropwise. After $20 \mathrm{~min}$ of stirring at -78 ${ }^{\circ} \mathrm{C}$, HMPA $(1.6 \mathrm{~mL}, 9.2 \mathrm{mmol})$ and $n-\mathrm{C}_{5} \mathrm{H}_{11} \mathrm{Br}(0.15 \mathrm{~mL}, 1.21 \mathrm{mmol})$ were added dropwise. The solution was allowed to gradually warm to rt over $10 \mathrm{~h}$ and diluted with saturated 
$\mathrm{NH}_{4} \mathrm{Cl}$ and hexane. The organic layer was separated and the aqueous layer was extracted with hexane three times. The combined organic layers were dried over $\mathrm{MgSO}_{4}$ and concentrated. The product was subjected to chromatography on silica gel (hexane/EtOAc) to isolate silyl ether 21 (197 mg, 83\% yield): $[\alpha]^{26}{ }_{D}+151\left(c 0.236, \mathrm{CHCl}_{3}\right)$; IR (neat) 1069 , $836 \mathrm{~cm}^{-1} ;{ }^{1} \mathrm{H}$ NMR (300 MHz, $\mathrm{CDCl}_{3}$ ) $\delta 0.07$ (s, $\left.6 \mathrm{H}\right), 0.89$ (br s, $\left.12 \mathrm{H}\right), 1.24-1.53$ (m, $\left.6 \mathrm{H}\right)$, 1.82-1.97 (m, 2 H), 2.08-2.22 (m, 4 H), 2.98-3.10 (m, 1 H), 4.92-5.00 (m, 1 H) 5.75 (dt, $J$ $=5.5,2 \mathrm{~Hz}, 1 \mathrm{H}), 5.88(\mathrm{ddd}, J=5.5,2,1 \mathrm{~Hz}, 1 \mathrm{H}) ;{ }^{13} \mathrm{C} \mathrm{NMR}\left(75 \mathrm{MHz}, \mathrm{CDCl}_{3}\right) \delta-4.5(-)$, $14.1(-), 18.4(+), 18.8(+), 22.3(+), 25.1(+), 26.1(-), 28.9(+), 31.1(+), 40.1(+), 44.1(-)$, $77.7(-), 78.5(+), 81.1(+), 134.4(-), 137.3(-)$.

(R)-4-(Oct-2-ynyl)cyclopent-2-enone (22). To an ice-cold solution of silyl ether 21 (389 mg, $1.27 \mathrm{mmol})$ in THF (3 mL) was added $\mathrm{Bu}_{4} \mathrm{NF}(3.80 \mathrm{~mL}, 1.0 \mathrm{M}$ in THF, 3.80 mmol) dropwise. The solution was stirred at $50{ }^{\circ} \mathrm{C}$ for $2 \mathrm{~h}$ before dilution with saturated $\mathrm{NH}_{4} \mathrm{Cl}$ and EtOAc with vigorous stirring. The phases were separated and the aqueous layer was extracted with EtOAc three times. The combined organic layers were dried over $\mathrm{MgSO}_{4}$ and concentrated to obtain the corresponding alcohol, which was used for the next reaction without further purification: characteristic signals of ${ }^{1} \mathrm{H} \mathrm{NMR}\left(300 \mathrm{MHz}, \mathrm{CDCl}_{3}\right) \delta$ $0.88(\mathrm{t}, J=8 \mathrm{~Hz}, 3 \mathrm{H}), 1.24-1.52$ (m, $6 \mathrm{H}), 1.66$ (br s, $1 \mathrm{H}), 1.88-1.98$ (m, $2 \mathrm{H}), 2.07-2.22$ $(\mathrm{m}, 4 \mathrm{H}), 2.98-3.11(\mathrm{~m}, 1 \mathrm{H}), 4.89(\mathrm{~s}, 1 \mathrm{H}), 5.86(\mathrm{dt}, J=5.5,2 \mathrm{~Hz}, \quad 1 \mathrm{H}), 5.88(\mathrm{ddd}, J=$ $5.5,2,1 \mathrm{~Hz}, 1 \mathrm{H})$.

To a solution of the above alcohol and Celite $(1.0 \mathrm{~g})$ in $\mathrm{CH}_{2} \mathrm{Cl}_{2}(3 \mathrm{~mL})$ was added PCC (797 mg, $3.70 \mathrm{mmol}$ ). After being stirred vigorously for $2 \mathrm{~h}$, the mixture was diluted with hexane and filtered through a pad of Celite with hexane. The filtrate was concentrated to obtain an yellow residue, which was purified by chromatography (hexane/EtOAc) to furnish enone 22 (206 mg, 85\% yield from 21): $[\alpha]^{27}+192\left(c 0.112, \mathrm{CHCl}_{3}\right)$; IR (neat) 1716, $1181 \mathrm{~cm}^{-1} ;{ }^{1} \mathrm{H}$ NMR $\left(300 \mathrm{MHz}, \mathrm{CDCl}_{3}\right) \delta 0.88(\mathrm{t}, J=7 \mathrm{~Hz}, 3 \mathrm{H}), 1.21-1.50(\mathrm{~m}, 6 \mathrm{H})$, 2.05-2.20 (m, $3 \mathrm{H}), 2.29-2.50(\mathrm{~m}, 2 \mathrm{H}), 2.51(\mathrm{dd}, J=19,7 \mathrm{~Hz}, 1 \mathrm{H}), 3.06-3.16(\mathrm{~m}, 1 \mathrm{H})$, $6.20(\mathrm{dd}, J=5.5,2 \mathrm{~Hz}, 1 \mathrm{H}), 7.63(\mathrm{dd}, J=5.5,2 \mathrm{~Hz}, 1 \mathrm{H}) ;{ }^{13} \mathrm{C} \mathrm{NMR}\left(75 \mathrm{MHz}, \mathrm{CDCl}_{3}\right) \delta$ $14.1(-), 18.6(+), 22.2(+), 23.9(+), 28.6(+), 31.1(+), 40.1(+), 40.6(-), 76.0(+), 82.8(+)$, $134.7(-), 166.9(-), 209.5(+)$.

Methyl (5R,6S)-5,6-Epoxy-6-formylhexanoate (23). To an ice-cold solution of methyl (5R,6R)-5,6-epoxy-7-hydroxyheptanoate (655 mg, $3.76 \mathrm{mmol}), \mathrm{Et}_{3} \mathrm{~N}$ (3.20 mL, $\left.23.0 \mathrm{mmol}\right)$ 
and DMSO (5.3 mL, $74.7 \mathrm{mmol})$ in $\mathrm{CH}_{2} \mathrm{Cl}_{2}(16 \mathrm{~mL})$ was added $\mathrm{SO}_{3} \cdot$ pyridine $(1.80 \mathrm{~g}, 11.3$ $\mathrm{mmol})$. The solution was stirred vigorously at the same temperature for $1 \mathrm{~h}$ and poured into cold saturated $\mathrm{NaHCO}_{3}$ and $\mathrm{Et}_{2} \mathrm{O}$. The resulting mixture was stirred vigorously at $\mathrm{rt}$ for 20 min. The phases were separated and the aqueous layer was extracted with ether three times. The combined organic layers were dried over $\mathrm{MgSO}_{4}$ and concentrated. The crude product was passed through a short column of silica gel (hexane/EtOAc) to afford 23, which was used for the next reaction without further purification.

\section{Methyl $(5 R, 6 R, 7 E)-((2 S)-2-(O c t-2-y n y l)-5-o x o c y c l o p e n t-3-e n y l i d e n)-5,6-e p o x y-$} 7-heptanoate (25). To an ice-cold solution of $i$ - $\mathrm{Pr}_{2} \mathrm{NH}(0.28 \mathrm{~mL}, 2.00 \mathrm{mmol})$ in THF (5 $\mathrm{mL})$ was added $n$-BuLi $(0.92 \mathrm{~mL}, 1.63 \mathrm{M}$ in hexane, $1.50 \mathrm{mmol})$ dropwise. After $15 \mathrm{~min}$ at $0{ }^{\circ} \mathrm{C}$, the solution was cooled to $-78^{\circ} \mathrm{C}$, and enone $22(190 \mathrm{mg}, 0.999 \mathrm{mmol})$ dissolved in THF $(1 \mathrm{~mL})$ was added dropwise. The solution was stirred at $-78^{\circ} \mathrm{C}$ for $1 \mathrm{~h}$, and the above aldehyde 23 dissolved in THF ( $1 \mathrm{~mL})$ was added slowly. The solution was stirred at $-78^{\circ} \mathrm{C}$ for 30 min and poured into an ice-cold mixture of saturated $\mathrm{NH}_{4} \mathrm{Cl}$ and EtOAc with vigorous stirring. After a few minutes, the layers were separated and the aqueous layer was extracted with EtOAc three times. The combined organic layers were dried over $\mathrm{MgSO}_{4}$, and concentrated to afford aldol $\mathbf{2 4}$, which was used for the next reaction without further purification.

To an ice-cold solution of the above aldol 24 and $\mathrm{Et}_{3} \mathrm{~N}(1.41 \mathrm{~mL}, 10.0 \mathrm{mmol})$ in $\mathrm{CH}_{2} \mathrm{Cl}_{2}$ $(5 \mathrm{~mL})$ was added $\mathrm{MsCl}(0.31 \mathrm{~mL}, 4.00 \mathrm{mmol})$. The solution was stirred for $1 \mathrm{~h}$ at $0{ }^{\circ} \mathrm{C}$ and diluted with saturated $\mathrm{NaHCO}_{3}$ solution and EtOAc with vigorous stirring. The organic layer was separated, dried over $\mathrm{MgSO}_{4}$ and concentrated. The crude product was passed through a short column of silica gel (hexane/EtOAc) to afford the corresponding mesylate, which was used for the next reaction without further purification.

To a solution of the above mesylate in $\mathrm{CH}_{2} \mathrm{Cl}_{2}(5 \mathrm{~mL})$ was added $\mathrm{Al}_{2} \mathrm{O}_{3}(2.00 \mathrm{~g}, 19.6$ mmol) (Alumina $\mathrm{N}$ - Super I from ICN). The mixture was stirred at rt vigorously for $12 \mathrm{~h}$ and filtered through a pad of Celite with EtOAc. The filtrate was concentrated and the residual oil was purified by chromatography (hexane/EtOAc) to furnish dienone 25 (136 mg, 40\% yield from 22): $[\alpha]^{27}{ }_{D}+192\left(c 0.184, \mathrm{CHCl}_{3}\right)$; IR (neat) 1737, 1707, 1659, 1206 $\mathrm{cm}^{-1} ;{ }^{1} \mathrm{H}$ NMR $\left(300 \mathrm{MHz}, \mathrm{CDCl}_{3}\right) \delta 0.88(\mathrm{t}, J=7 \mathrm{~Hz}, 3 \mathrm{H}), 1.22-1.50(\mathrm{~m}, 6 \mathrm{H}), 1.52-1.92$ (m, $4 \mathrm{H}), 2.08$ (tt, $J=7,2.5 \mathrm{~Hz}, 2 \mathrm{H}), 2.32-2.41(\mathrm{~m}, 3 \mathrm{H}), 2.71$ (ddt, $J=17,5,2 \mathrm{~Hz}, 1 \mathrm{H}$ ), 2.94 (ddd, $J=7,5,2$ Hz, 1 H), 3.34 (dd, $J=8,2$ Hz, 1 H), 3.65 (s, 3 H), 3.68-3.75 (m, 1 
H), $6.21(\mathrm{~d}, J=6 \mathrm{~Hz}, 1 \mathrm{H}), 6.38(\mathrm{dd}, J=6,2 \mathrm{~Hz}, 1 \mathrm{H}), 7.63(\mathrm{ddd}, J=6,3,1 \mathrm{~Hz}, 1 \mathrm{H}) ;{ }^{13} \mathrm{C}$ NMR (75 MHz, $\left.\mathrm{CDCl}_{3}\right) \delta 14.0(-), 18.6(+), 21.3(+), 22.2(+), 24.1(+), 28.6(+), 31.0(+)$, $31.3(+), 33.4(+), 42.6(-), 51.7(-), 54.8(-), 60.0(-), 75.6(+), 83.6(+), 131.1(-), 135.0$ $(-), 140.0(+), 161.2(-), 173.5(+), 195.4(+)$.

\section{(5R,6R,7E)-((2S)-2-(Oct-2-ynyl)-5-oxocyclopent-3-enyliden)-5,6-epoxy-7-}

heptanoic Acid (26). A mixture of methyl ester 25 (73 mg, $0.21 \mathrm{mmol}$ ) and PPL (100 mg) (lipase from porcine pancreas, Type II from Sigma) in acetone $(0.4 \mathrm{~mL})$ and phosphate

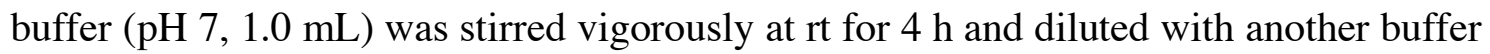
$(\mathrm{pH} 4)$ and EtOAc. The organic layer was separated and the aqueous layer was extracted with EtOAc several times. The combined organic layers were dried over $\mathrm{MgSO}_{4}$ and concentrated. The crude product was subjected to chromatography on silica gel (hexane/EtOAc) to isolate acid 26 (38 mg, 55\% yield): $[\alpha]_{\mathrm{D}}^{27}+164\left(c 0.118, \mathrm{CHCl}_{3}\right)$; IR (neat) 3320, 1707, 1657, $1208 \mathrm{~cm}^{-1} ;{ }^{1} \mathrm{H}$ NMR $\left(300 \mathrm{MHz}, \mathrm{CDCl}_{3}\right) \delta 0.89$ (t, $\left.J=7 \mathrm{~Hz}, 3 \mathrm{H}\right)$, 1.22-1.54 (m, $6 \mathrm{H}), 1.56-1.94(\mathrm{~m}, 4 \mathrm{H}), 2.08$ (tt, $J=7,2.5 \mathrm{~Hz}, 2 \mathrm{H}), 2.30-2.52(\mathrm{~m}, 3 \mathrm{H})$, 2.71 (ddt, $J=17,5,2 \mathrm{~Hz}, 1 \mathrm{H}), 2.98$ (ddd, $J=6,5,2 \mathrm{~Hz}, 1 \mathrm{H}), 3.38$ (dd, $J=8,2 \mathrm{~Hz}, 1 \mathrm{H}$ ), 3.69-3.78 (m, $1 \mathrm{H}), 6.21$ (d, $J=8 \mathrm{~Hz}, 1 \mathrm{H}), 6.41$ (dd, $J=6,2 \mathrm{~Hz}, 1 \mathrm{H}), 7.63$ (ddd, $J=6,3$, $1 \mathrm{~Hz}, 1 \mathrm{H}) ;{ }^{13} \mathrm{C} \mathrm{NMR}\left(75 \mathrm{MHz}, \mathrm{CDCl}_{3}\right) \delta 14.1(-), 18.7(+), 21.2(+), 22.2(+), 24.2(+)$, $28.6(+), 31.1(+), 31.3(+), 33.4(+), 42.7(-), 54.9(-), 60.1(-), 75.6(+), 83.7(+), 131.2$ $(-), 135.0(-), 140.1(+), 161.5(-), 178.7(+), 195.6(+)$.

2-(14,15-Dehydro-5,6-epoxyisoprostane $\left.A_{2}\right)$ phosphorylcholine (18b). To a mixture of lyso-PC (27) (18 mg, $0.036 \mathrm{mmol})$ and DMAP (68 mg, $0.56 \mathrm{mmol})$ in $\mathrm{CH}_{2} \mathrm{Cl}_{2}(1 \mathrm{~mL})$ was added a solution of acid $26(26 \mathrm{mg}, 0.078 \mathrm{mmol})$ in $\mathrm{CH}_{2} \mathrm{Cl}_{2}(0.5 \mathrm{~mL})$. After $10 \mathrm{~min}$, 2,4,6- $\mathrm{Cl}_{3} \mathrm{C}_{6} \mathrm{H}_{2} \mathrm{COCl}(0.058 \mathrm{~mL}, 0.37 \mathrm{mmol})$ was added to the solution. The mixture was stirred at $\mathrm{rt}$ for $2 \mathrm{~h}$ and concentrated to give a residue, which was purified by chromatography on silica gel $\left(\mathrm{CH}_{2} \mathrm{Cl}_{2} / \mathrm{MeOH}\right)$ to afford a mixture of $\mathbf{1 8 b}(16 \mathrm{mg}, 55 \%$ yield) and DMAP (ca $1 \mathrm{mg}$ ) by ${ }^{1} \mathrm{H}$ NMR spectroscopy. 18b: ${ }^{1} \mathrm{H}$ NMR (300 $\left.\mathrm{MHz}, \mathrm{CDCl}_{3}\right) \delta$ 0.78-0.96 (m, $6 \mathrm{H}), 1.1-1.9$ (m, 36 H), 2.09-2.16 (m, $2 \mathrm{H}), 2.22-2.45$ (m, $5 \mathrm{H}), 2.68-2.78$ (m, $1 \mathrm{H}), 2.95-2.98(\mathrm{~m}, 1 \mathrm{H}), 3.20-3.52$ (m, $10 \mathrm{H}), 3.60-3.84(\mathrm{~m}, 3 \mathrm{H}), 3.88-4.02$ (m, $2 \mathrm{H})$, 4.08-4.44 (m, 4 H), 5.21 (br s, 1 H), 6.22 (d, J=8 Hz, 1 H), 6.40 (dd, $J=6,2$ Hz, 1 H), 7.62-7.70 (m, $1 \mathrm{H})$. 
Methyl (5R,6R,7E)-((2S)-2-((2E)-Oct-2-enyl)-5-oxocyclopent-3- enyliden)-5,6epoxy-7-heptanoate (28). A mixture of $5 \% \mathrm{Pd} / \mathrm{BaSO}_{4}(1.5 \mathrm{mg})$ and quinoline $(0.045 \mathrm{~mL})$ in $\mathrm{MeOH}(1 \mathrm{~mL})$ was stirred at $\mathrm{rt}$ for 10 min under argon, which was then replaced by hydrogen. The mixture was stirred for $30 \mathrm{~min}$ and alkyne 25 (36 mg, $0.10 \mathrm{mmol}$ ) was added to it. After $1.5 \mathrm{~h}$, the mixture was filtered through a pad of Celite with hexane. The filtrate was concentrated to obtain an yellow residue, which was purified by chromatography (hexane/EtOAc) to furnish alkene 28 (28 mg, 78\%). The ${ }^{1} \mathrm{H}$ NMR spectrum of the product was consistent with that reported previously from our group. ${ }^{8}$ 


\section{References}

(1) Brown, H. C.; Khire, U. R.; Narla, G.; Racherla, U. S. J. Org. Chem. 1995, 60, 544.

(2) Maddess, M. L.; Lautens, M. Org. Lett. 2005, 7, 3557.

(3) Danheiser, R. L.; Carini, D. J.; Kwasigroch, C. A. J. Org. Chem. 1986, 51, 3870.

(4) Sidduri, A.; Rozema, M.; Knochel, P. J. Org. Chem. 1993, 58, 2694.

(5) Compain, P.; Gore, J.; Vatele, J.-M. Tetrahedron 1996, 52, 10405.

(6) Tanaka, H.; Hasegawa, T.; Iwashima, M.; Iguchi, K.; Takahashi, T. Org. Lett. 2004, 6, 1103.

(7) Curran, T. T.; Hay, D. A.; Koegel, C. P. Tetrahedron 1997, 53, 1983.

(8) Acharya, H. P.; Kobayashi, Y. Angew. Chem. Int. Ed. 2005, 44, 3481. 


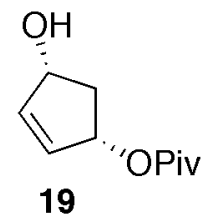

${ }^{1} \mathrm{H}$ NMR $\left(300 \mathrm{MHz}, \mathrm{CDCl}_{3}\right)$
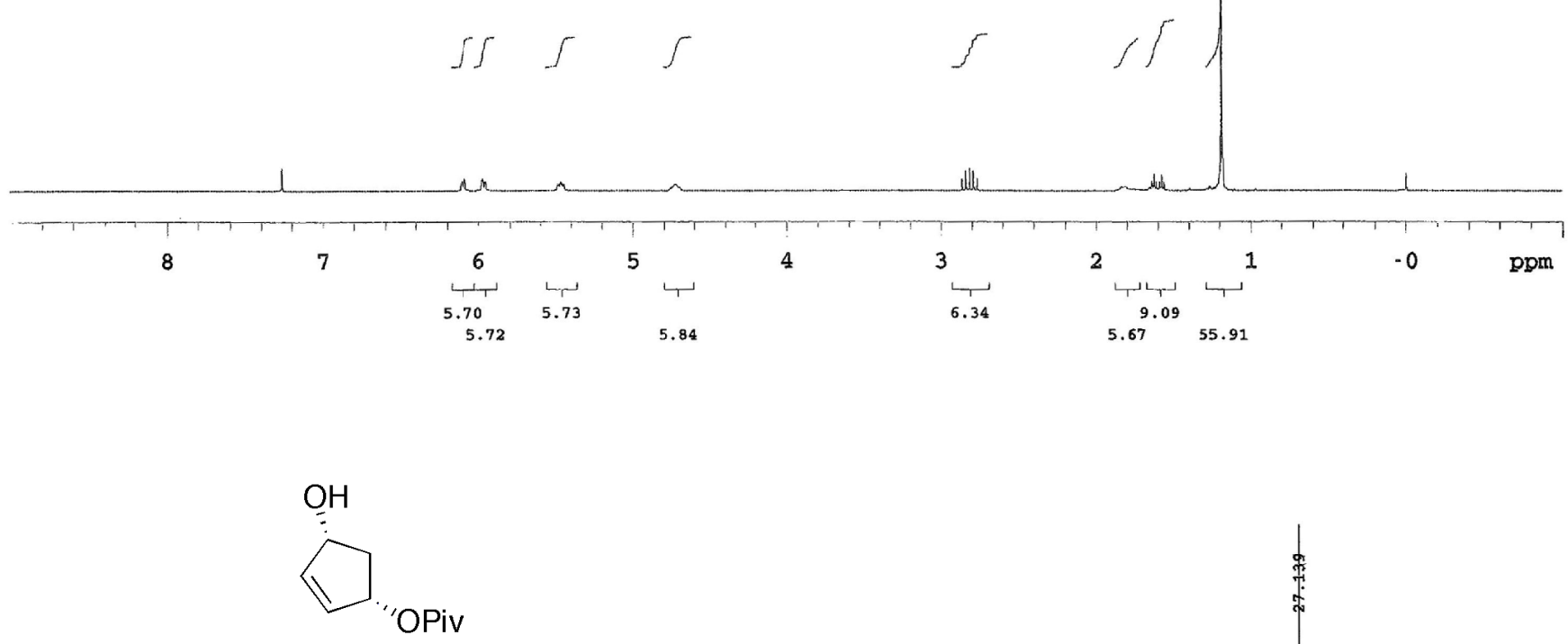

19

${ }^{13} \mathrm{C}$ NMR $\left(75 \mathrm{MHz}, \mathrm{CDCl}_{3}\right)$

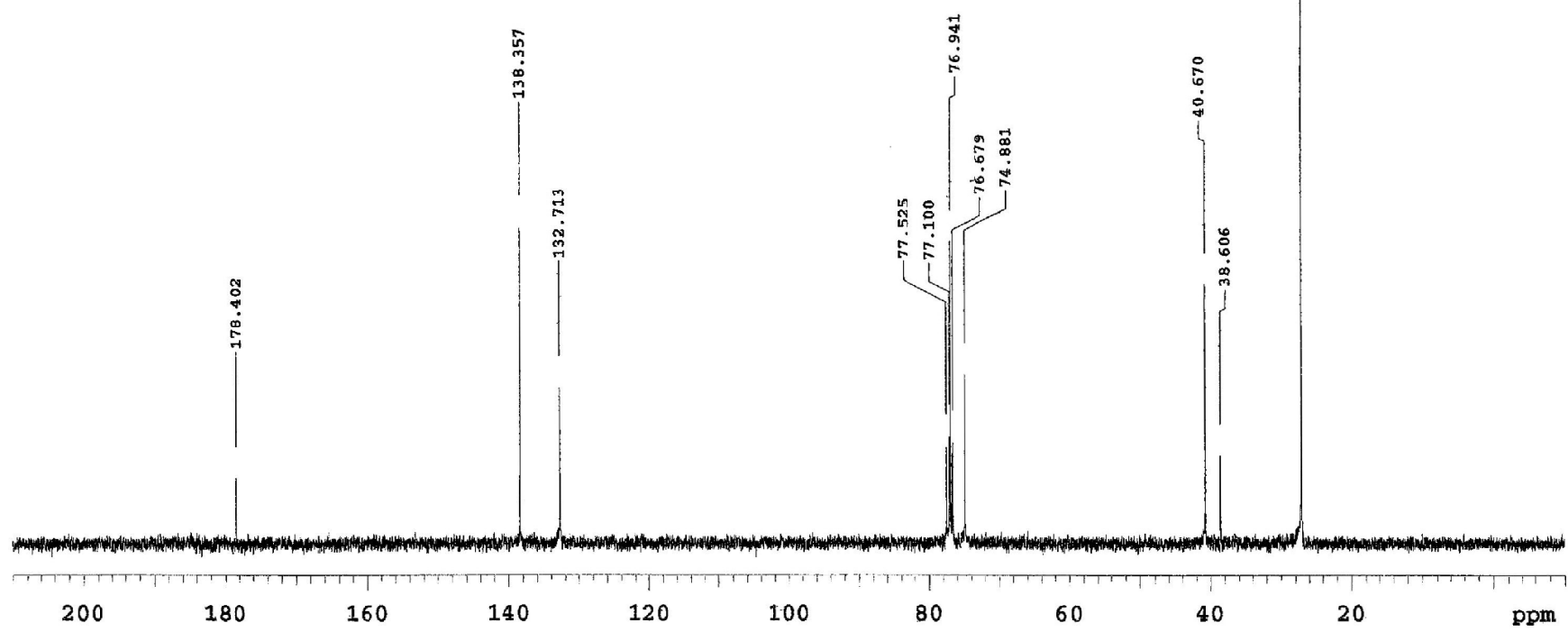




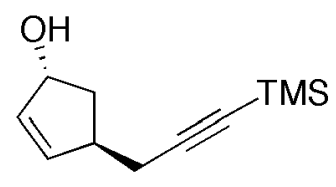

(1R)-16

${ }^{1} \mathrm{H}$ NMR (300 MHz, $\mathrm{CDCl}_{3}$ )
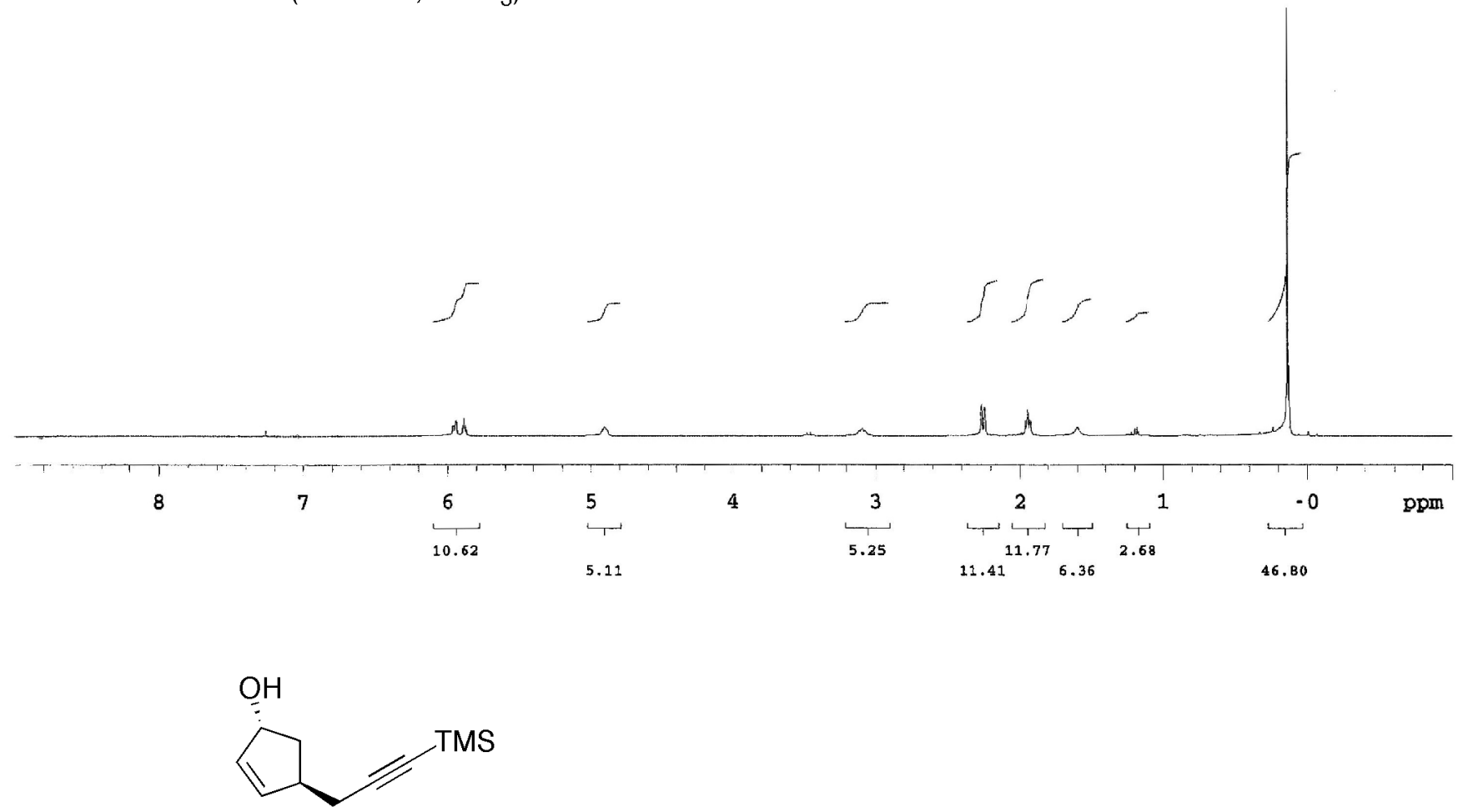

(1R)-16

${ }^{13} \mathrm{C} \mathrm{NMR}\left(75 \mathrm{MHz}, \mathrm{CDCl}_{3}\right)$

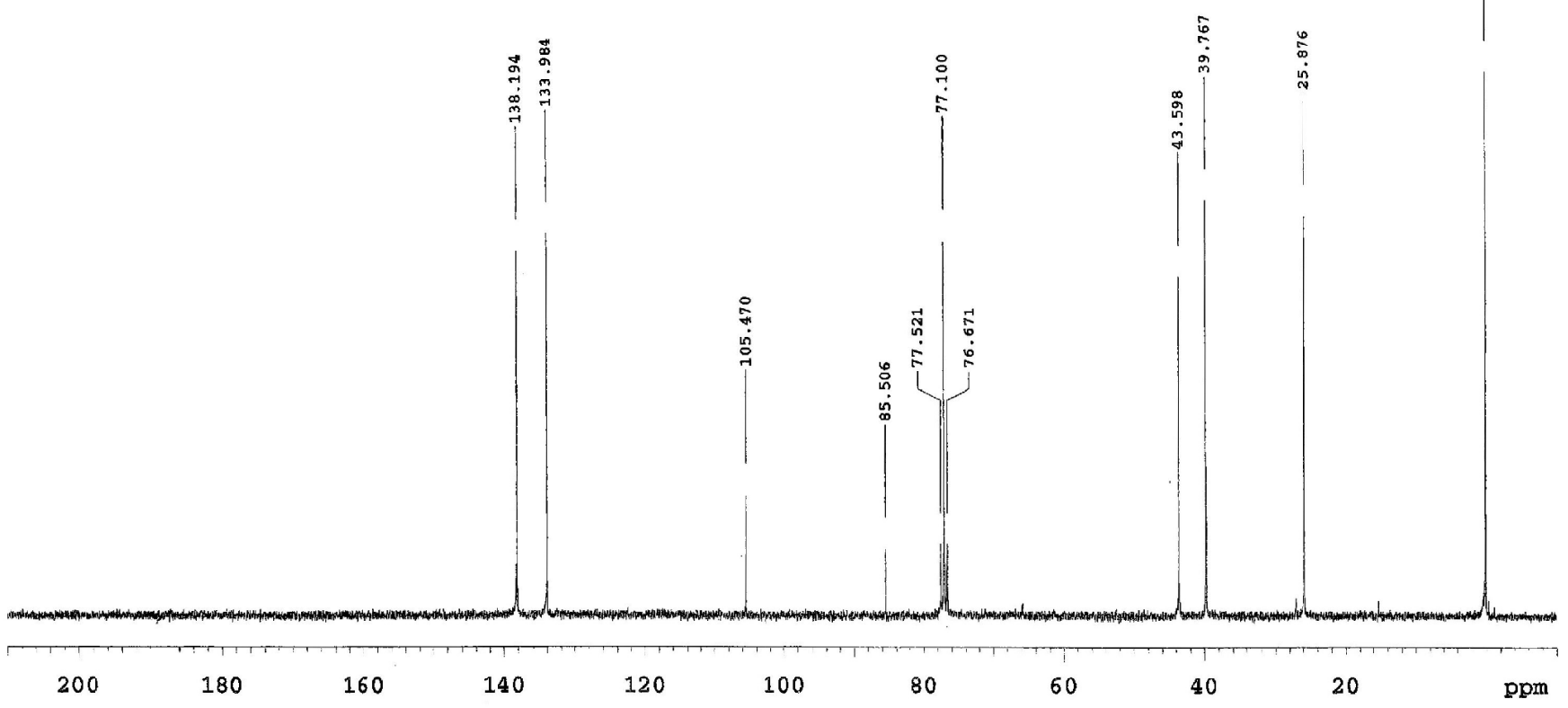


ODTBS

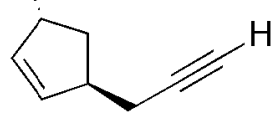

20

${ }^{1} \mathrm{H}$ NMR $\left(300 \mathrm{MHz}, \mathrm{CDCl}_{3}\right)$

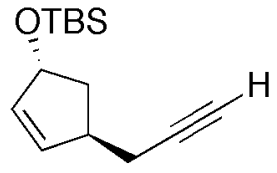

20

${ }^{13} \mathrm{C}$ NMR (75 MHz, $\mathrm{CDCl}_{3}$ )
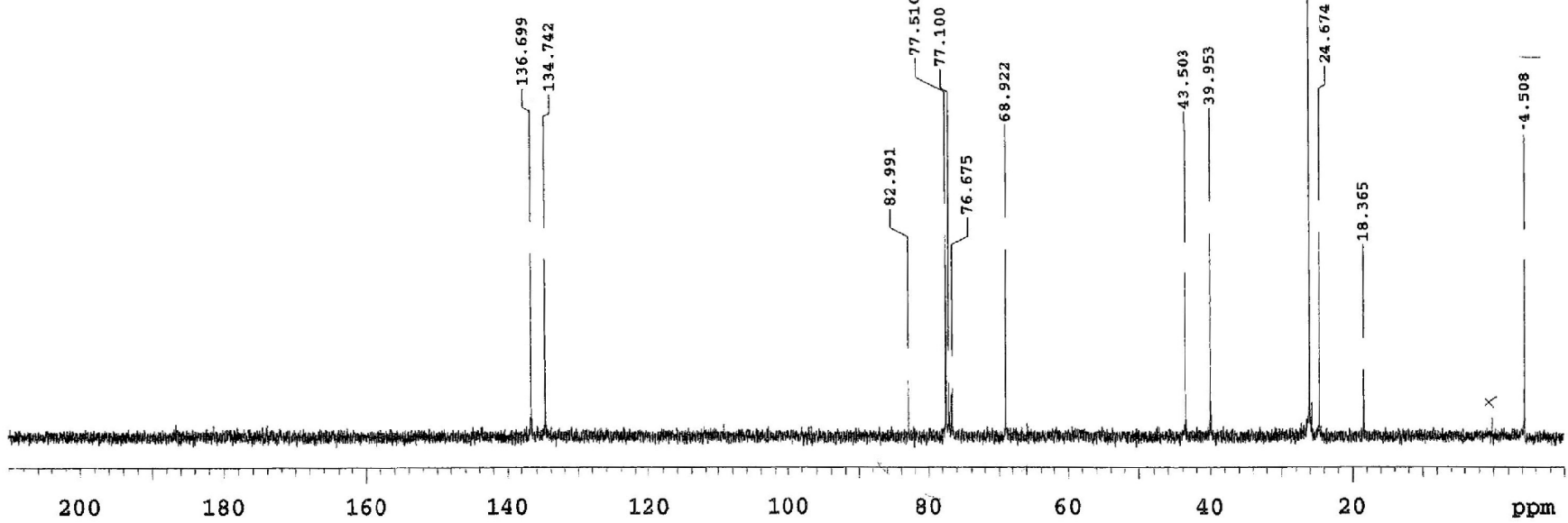


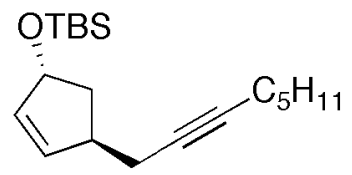

21

${ }^{1} \mathrm{H}$ NMR (300 MHz, $\mathrm{CDCl}_{3}$ )

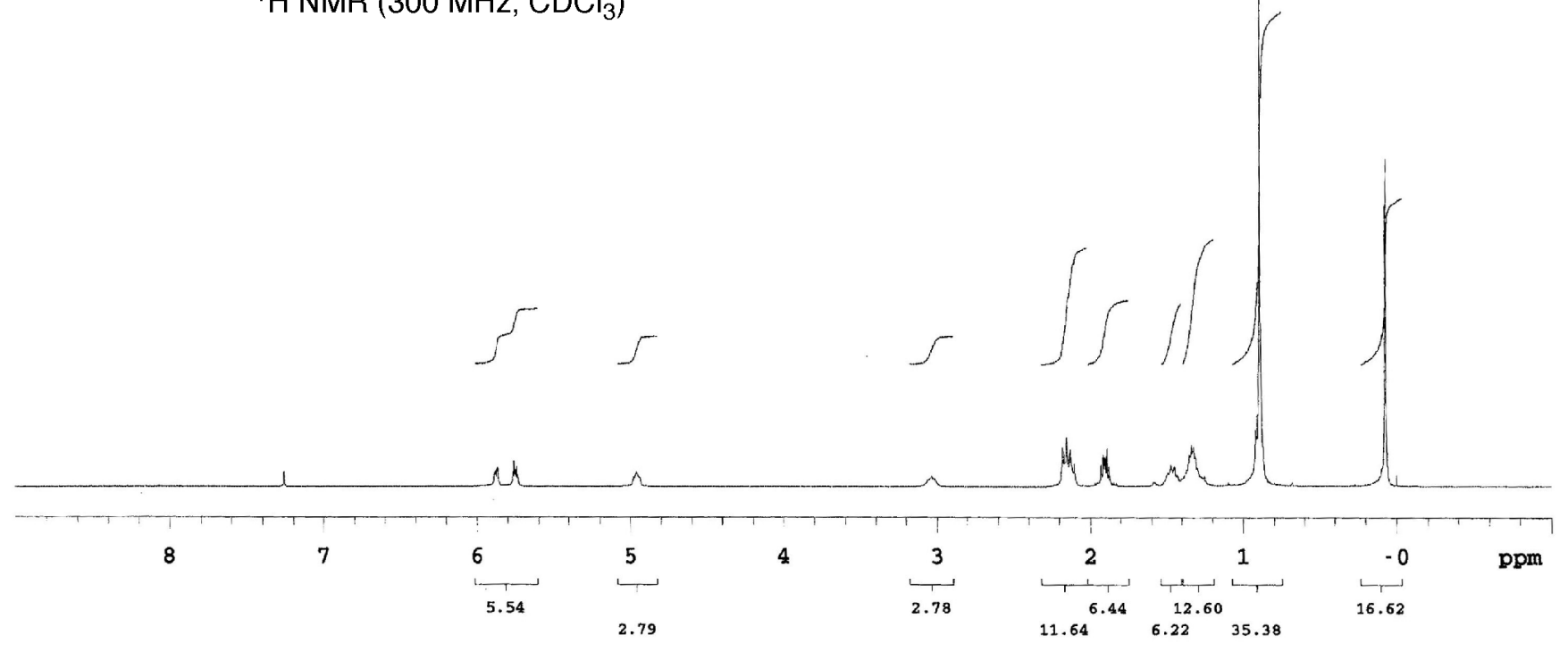

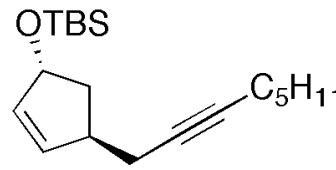

21

${ }^{13} \mathrm{C}$ NMR $\left(75 \mathrm{MHz}, \mathrm{CDCl}_{3}\right)$

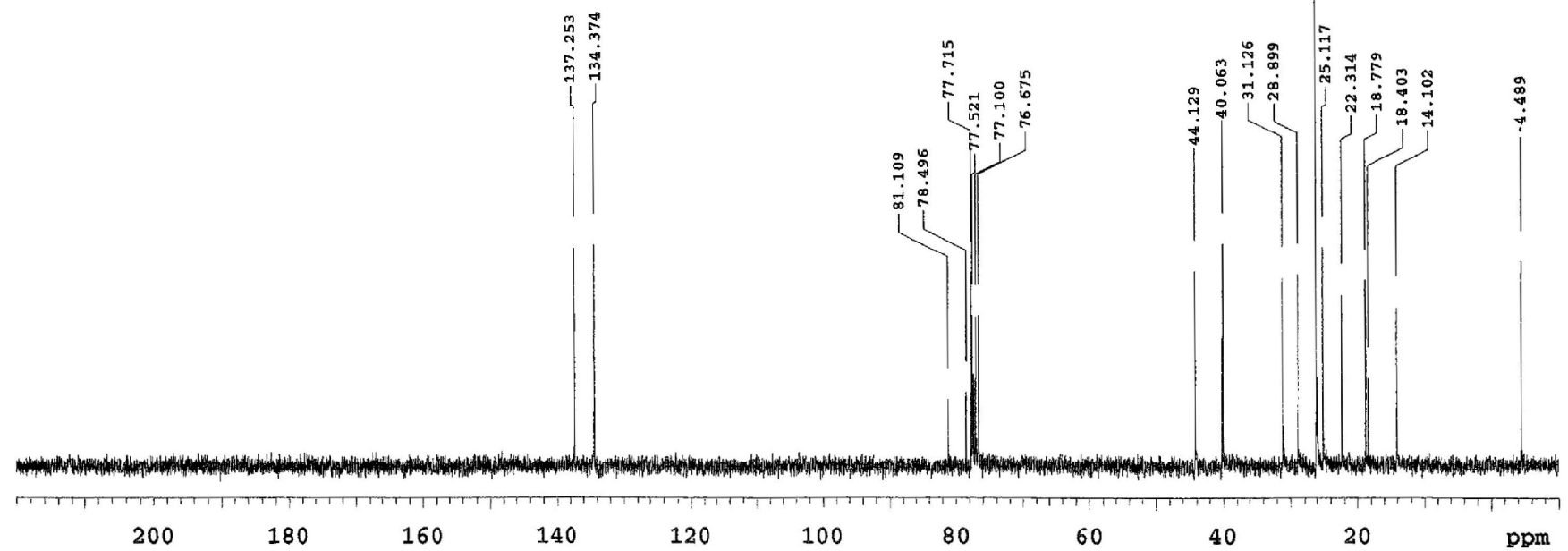




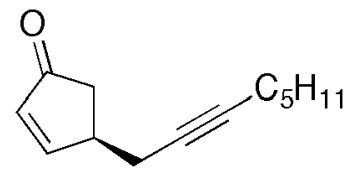

22

${ }^{1} \mathrm{H}$ NMR (300 MHz, $\mathrm{CDCl}_{3}$ )
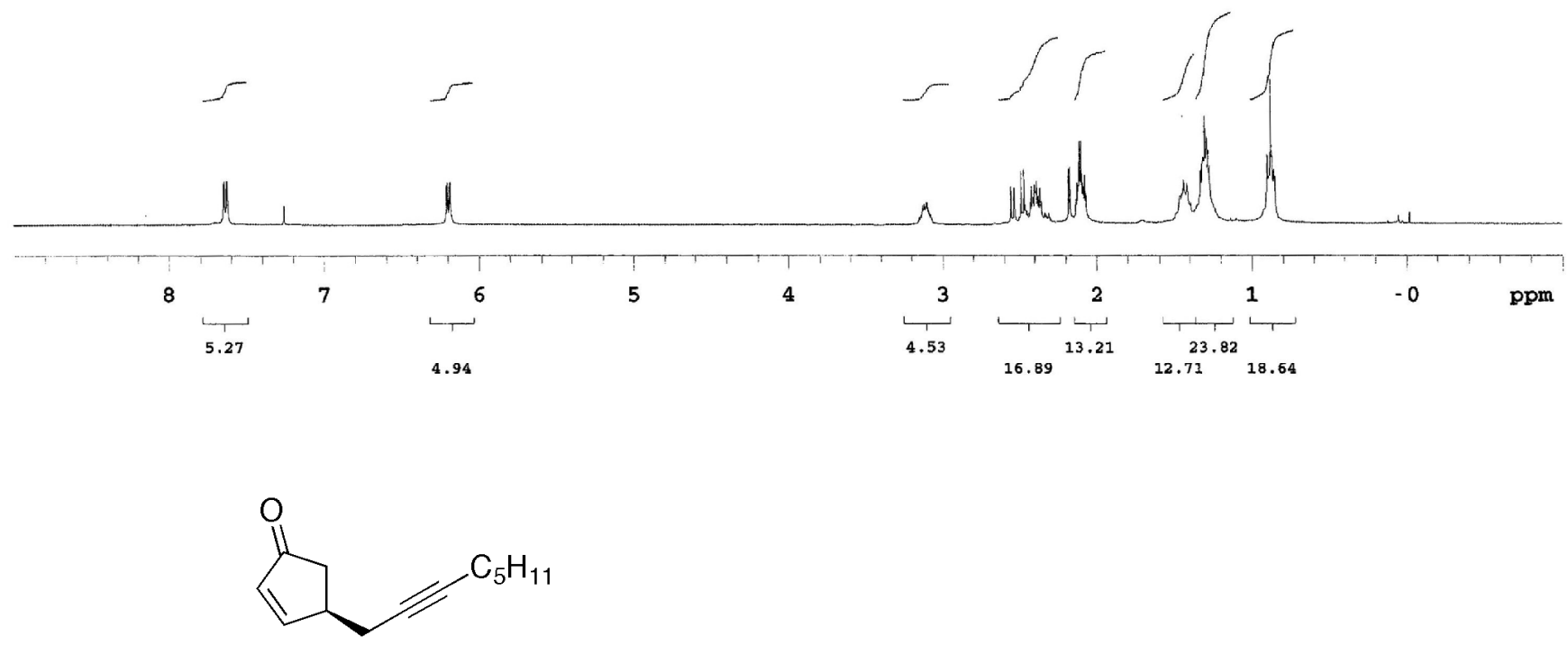

22

${ }^{13} \mathrm{C}$ NMR $\left(75 \mathrm{MHz}, \mathrm{CDCl}_{3}\right)$

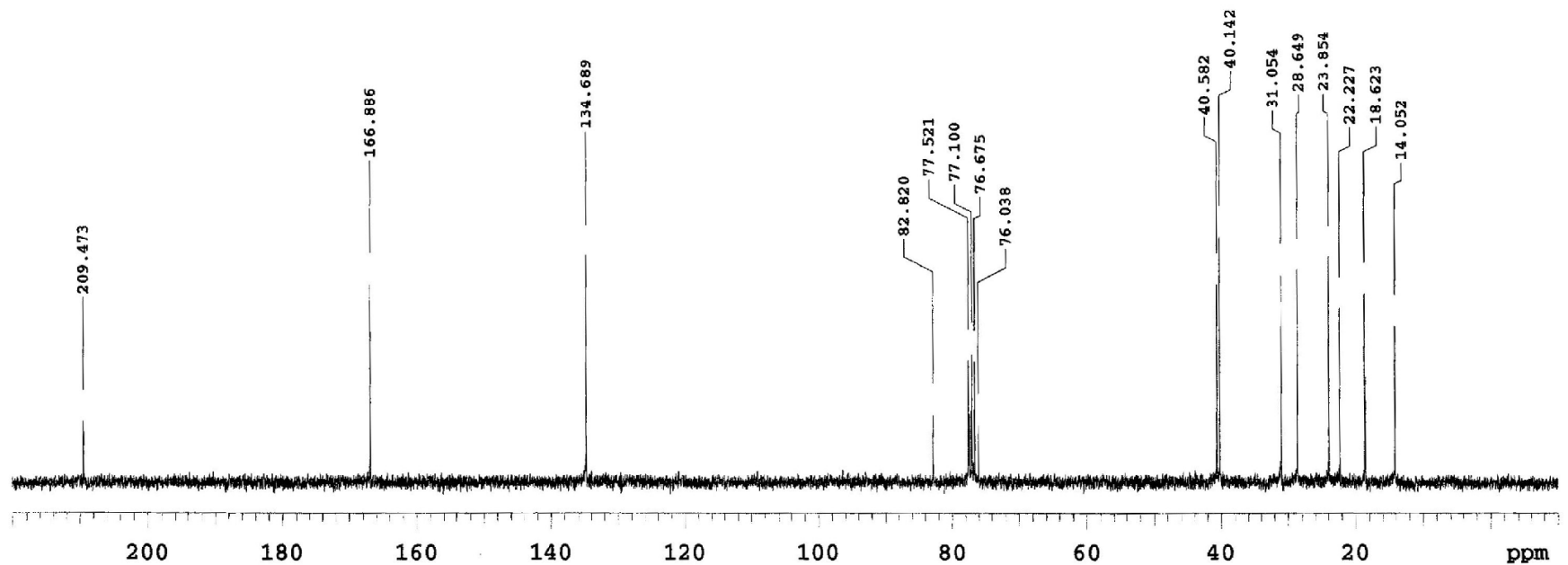




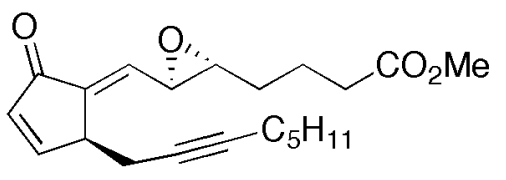

25

${ }^{1} \mathrm{H}$ NMR $\left(300 \mathrm{MHz}, \mathrm{CDCl}_{3}\right.$ )
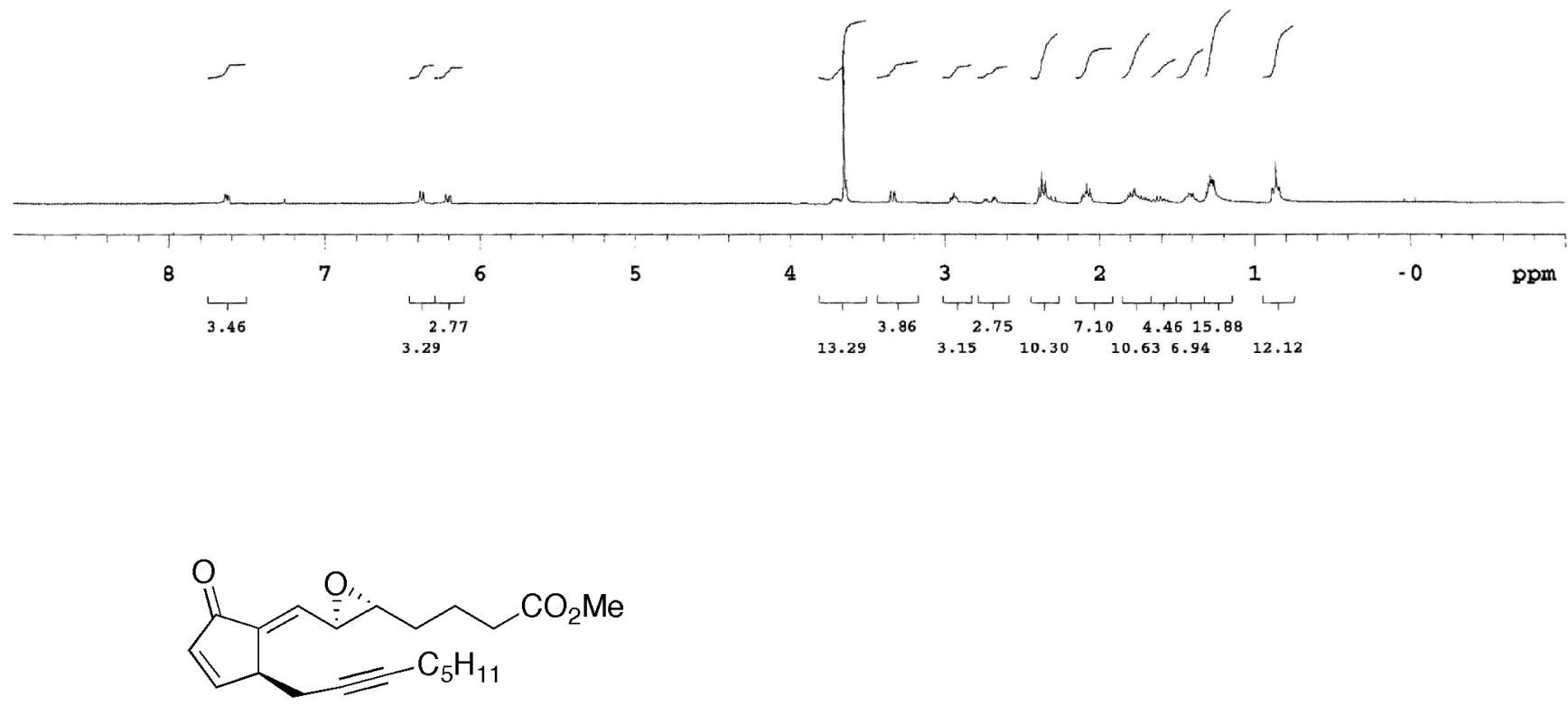

25

${ }^{13} \mathrm{C}$ NMR $\left(75 \mathrm{MHz}, \mathrm{CDCl}_{3}\right)$

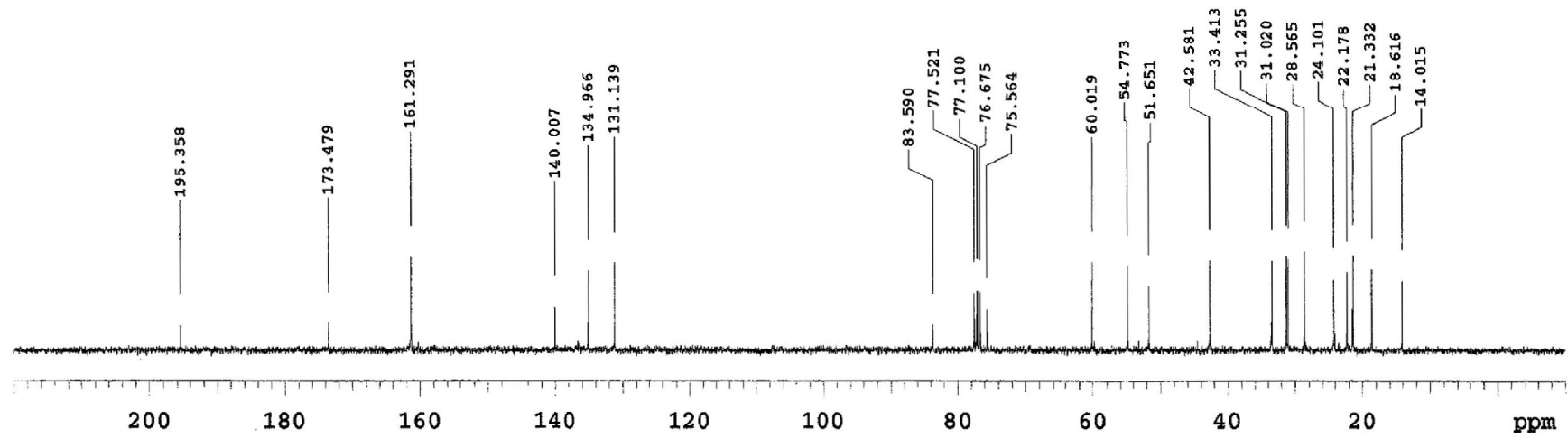




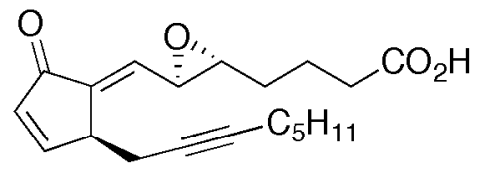

26

${ }^{1} \mathrm{H}$ NMR $\left(300 \mathrm{MHz}, \mathrm{CDCl}_{3}\right)$

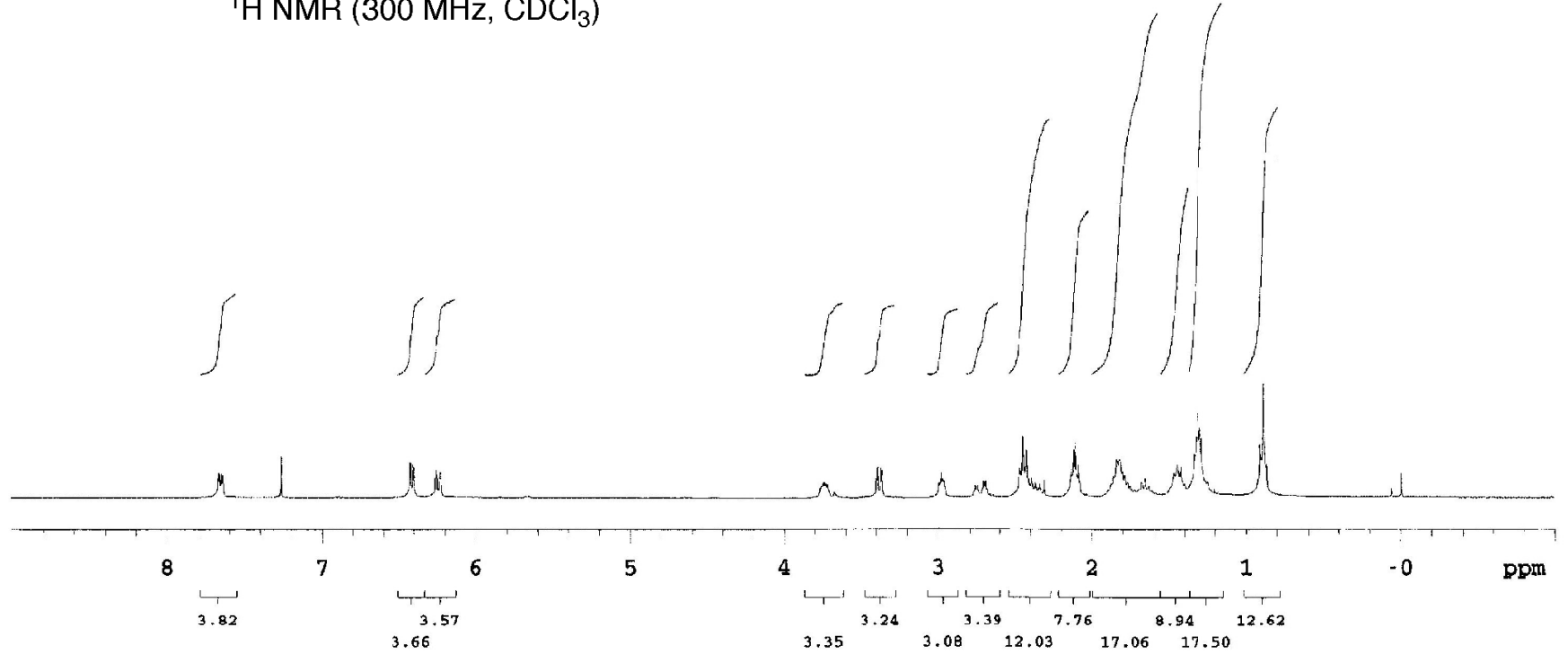<smiles>O=C(O)CCCCC#CCC1C=CC(=O)/C1=C/C1OC1CCCC(=O)O</smiles>

26

${ }^{13} \mathrm{C}$ NMR $\left(75 \mathrm{MHz}, \mathrm{CDCl}_{3}\right)$

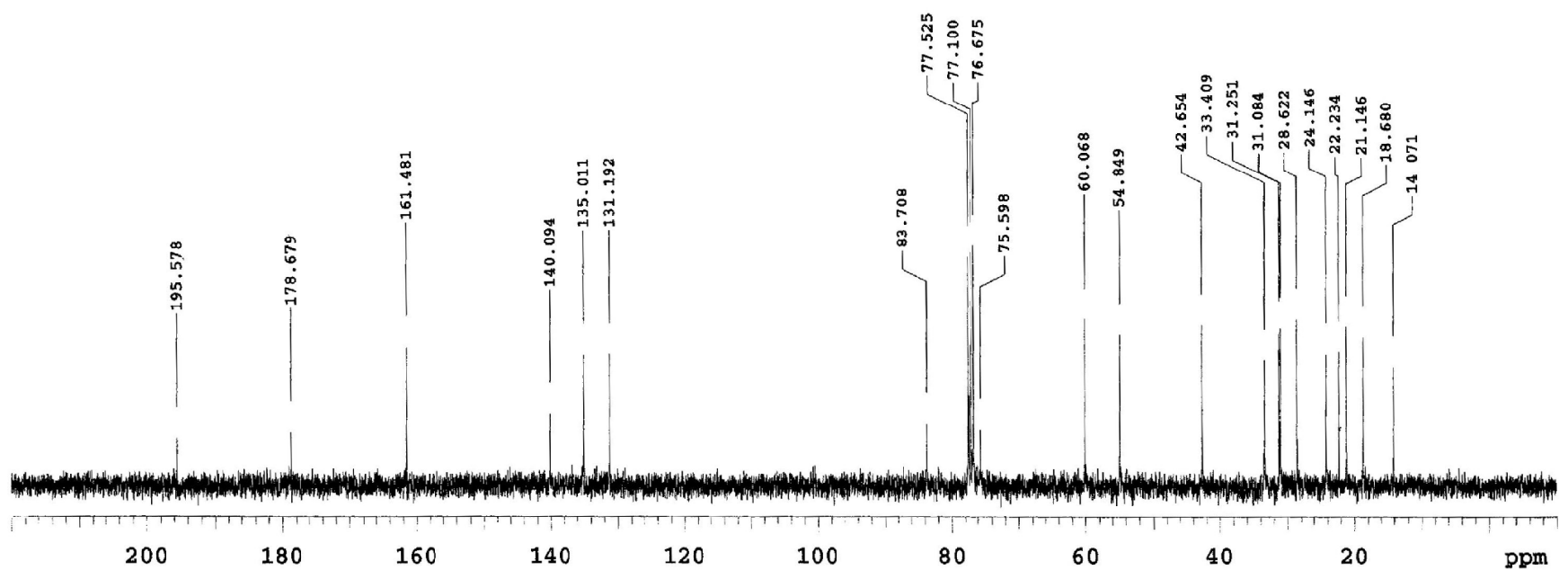

